\title{
Big projects cited as threat to NSF's integrity
}

Geoff Brumfiel, Washington

The integrity of the US National Science Foundation (NSF) could be called into question because of its backlog of competing major projects, observers claim.

The warning came at a hearing on 2 August of a National Academy of Sciences panel set up to study how the NSF selects such projects. Congressional staff warned the panel that the number of approved but so far unfunded projects was encouraging Congress to choose those that the NSF should fund. This could cost the agency its cherished reputation for scientific objectivity, they said, and perhaps lead it into territory where political factors, rather than scientific merit, would determine project funding.

But NSF director Rita Colwell denies that the problem exists, and says that the agency's selection process is in good shape.

In the past few years, the National Science Board, which governs the NSF, has approved several multimillion-dollar projects that the agency has not felt able to fund for construction. At least six projects are currently in this backlog - and researchers involved in them are increasingly bypassing the NSF and going straight to Congress to seek funding, staff told the meeting.

One such project is IceCube, a neutrino detector to be built in the Antarctic. This was approved by the science board in 2001, but the NSF has yet to request funds for it. Francis Halzen of the University of Wisconsin at Madison, who directs the project, met with the staff of the House of Representatives appropriations subcommittee that funds the NSF - " "at their request", he says — to discuss IceCube. As a result, he secured \$15 million to begin work on the project this year.

Another project, the High-performance Instrumented Airborne Platform for Environmental Research (HIAPER), which will study the troposphere using an aircraft, was approved by the science board in 1998, but is yet to appear in an NSF budget request. Congress, however, added $\$ 35$ million for the project to this year's NSF budget.

Congressional staff also reported strong pressure to squeeze funding for a proposed \$280-million underground physics laboratory at the Homestake mine near Lead, South Dakota, into the NSF's budget. The project has yet to undergo scientific review, but it is strongly backed by both main political parties, who are facing off in a fiercely competitive Senate election in South Dakota this November. One congressional staff member, claimed that pressure to begin the project is threatening to bypass the entire approval process of the National Science Board.

"The volume of people coming to Capitol Hill from the science community is increasing," Joel Widder, a staff member on the Sen-

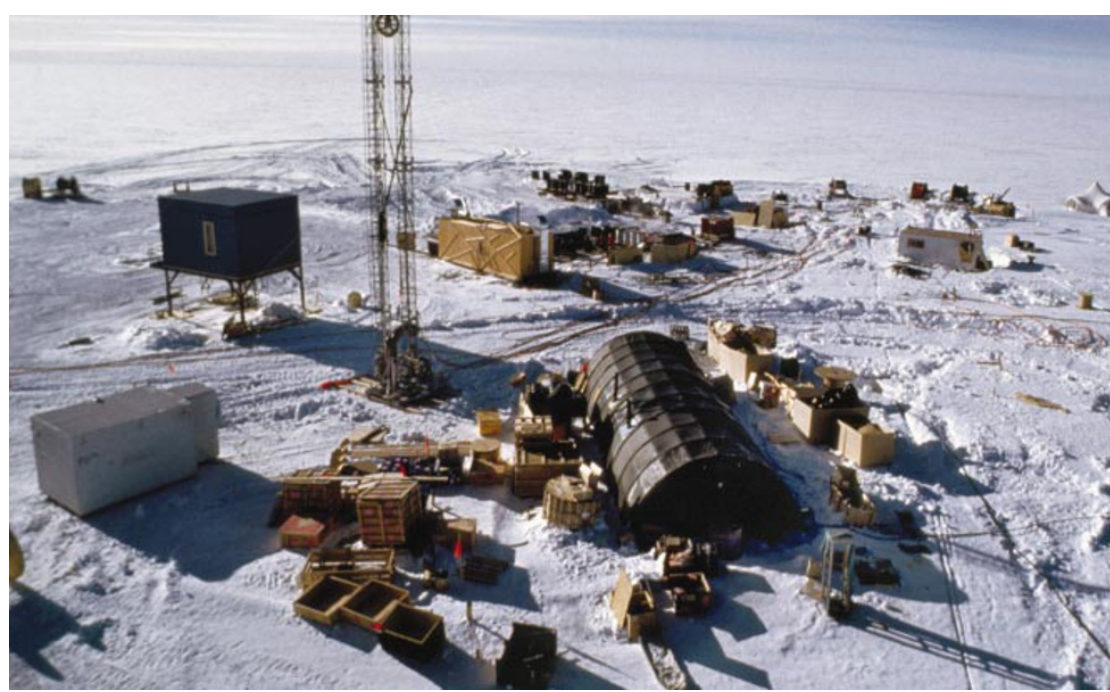

The IceCube project has jumped its place in the funding queue, thanks to congressional intervention.

ate subcommittee responsible for NSF's budget, told the panel. Cheh Kim, another staff member, asked the panel - which was convened at the request of a group of senators who say they champion the NSF's independence — to help to establish criteria for prioritizing NSF projects. Meantime, Senate appropriators have slashed next year's funding for major

\section{Test-ban treaty 'scientifically sound'}

\section{Geoff Brumfiel, Washington}

The Comprehensive Nuclear-Test-Ban Treaty (CTBT), rejected by the Senate nearly three years ago, has been pronounced technically sound by a panel of leading US scientists.

The treaty, which aims to prohibit nuclear testing worldwide, was signed by then president Bill Clinton in 1996, but the Senate voted against its ratification in October 1999.

Opponents of the CTBT — including leading members of the Bush administration - have argued that the treaty's terms would not allow the United States to detect testing abroad, and that adherence to it would threaten the country's own nuclear capability. Some want the administration to withdraw its signature from the unratified treaty.

But in a study released on 31 July, the National Academy of Sciences takes issue with these arguments. John Holdren, director of a science, technology and publicpolicy programme at Harvard University, and the chairman of the committee that drafted the report, says that using the monitoring system stipulated by the treaty, the United States would be able to detect tests as low as 1 or 2 kilotons virtually
NSF projects (see Nature 418, 472;2002).

But Colwell contends that the problem of congressional interference with NSF project decisions is under control. "I think the process is working very well and has been for 50 years," she says. She doubts whether the academy's review will lead to any drastic changes in the process. anywhere on Earth or in space. Attempts to mask a blast would fail unless the country had extensive previous testing experience. And such countries, including Russia and China, would have little to gain from lowyield, clandestine testing, he claims.

The study also finds that the United States could maintain its own stockpile of nuclear weapons indefinitely without further testing.

"This is the most authoritative and detailed assessment of the test-ban treaty to date," says Daryl Kimball, executive director of the Arms Control Association, which advocates ratification of the test ban. "It should give the Bush administration reason to reconsider its fundamental points of contention on the CTBT."

But Ivan Eland, director of defence policy studies at the Cato Institute, a libertarian think-tank, doubts whether it will have much impact on administration policy. "To me, it doesn't make sense to sign up for a treaty if you might have to test new weapons," he says.

The Bush administration opposes ratification of the treaty, but it continues to observe the US moratorium on testing that was begun in 1992.

"www.nap.edu/books/0309085063/html 